\title{
COX2/PTGS2 Expression Is Predictive of Response to Neoadjuvant Celecoxib in HER2-negative Breast Cancer Patients
}

\author{
PATRICIA DE CREMOUX ${ }^{1,2}$, ANNE-SOPHIE HAMY ${ }^{3}$, JACQUELINE LEHMANN-CHE ${ }^{1,2}$, \\ VÉRONIQUE SCOTT ${ }^{4}$, BRIGITTE SIGAL ${ }^{5}$, MARIE-CHRISTINE MATHIEU ${ }^{6}$, PHILIPPE BERTHEAU B $^{2,3,4,5,6,7}$ \\ JEAN MARC GUINEBRETIÈRE ${ }^{8}$, JEAN YVES PIERGA ${ }^{9,10}$, SYLVIE GIACCHETTI $^{11}$, ETIENNE BRAIN ${ }^{12}$, \\ MICHEL MARTY ${ }^{13}$, BERNARD ASSELAIN ${ }^{14}$, FRÉDÉRIQUE SPYRATOS $^{15^{*}}$ and IVAN BIÈCHE ${ }^{15^{*}}$ \\ ${ }^{1}$ Molecular Oncology Unit, ${ }^{7}$ Pathology Department, ${ }^{11}$ Breast Disease Unit, \\ Assistance Publique-Hôpitaux de Paris, University Saint-Louis Hospital, Paris, France; \\ ${ }^{2}$ University Paris-Diderot, Sorbonne Paris Cité, INSERM/CNRS UMR944/7212, Paris, France; \\ ${ }^{3}$ PSL Research University, Translational Research Department INSERM U932, Immunity and Cancer, \\ Residual Tumor \& Response to Treatment Laboratory (RT2 Lab), ${ }^{5}$ Pathology Department, \\ ${ }^{9}$ Medical Oncology Department, and ${ }^{15}$ Pharmacogenomics Unit, Curie Institute, Paris, France; \\ ${ }^{4}$ Translational Research Laboratory, and ${ }^{6}$ Pathology Department, Gustave Roussy Cancer Center, Villejuif, France; \\ ${ }^{8}$ Tumor Biology Department, ${ }^{12}$ Medical Oncology Department, Curie Institute, Saint-Cloud, France; \\ ${ }^{10}$ University Paris-Descartes, Sorbonne Paris Cité, Paris, France; \\ ${ }^{13}$ Centre for Therapeutic Innovations in Oncology and Hematology, \\ Assistance Publique-Hôpitaux de Paris, Saint-Louis Hospital, Paris, France; \\ ${ }^{14}$ UMR 8081 "IM4R", Université Paris Sud, Paris, France
}

\begin{abstract}
Background: The prognostic and predictive role of cyclo-oxygenase-2 (COX2) in breast cancer is still debated, and in particular, its role as a target of COX2 inhibitor (celecoxib) in neoadjuvant setting. Materials and Methods: We analyzed a series of 156 breast cancer samples from patients of the COX2 inhibitor-treated arm included in the REMAGUS02 randomized phase II trial. COX2 gene expression was assessed by reverse transcription and quantitative polymerase chain reaction using ribonucleic acid from frozen biopsies. Pathological complete response ( $p C R$ ) was the surrogate endpoint. Results: Significantly higher rates of grade 3, and estrogen and progesterone receptor negativity were observed in tumors with the highest expression of COX2. pCR rates were significantly higher in COX2-overexpressing tumors in
\end{abstract}

This article is freely accessible online.

*These Authors contributed equally to this study.

Correspondence to: Dr. Patricia de Cremoux, Molecular Oncology Unit, Saint-Louis Hospital, 1 avenue Claude Vellefaux, 75010 Paris, France. Tel +33 142499388. e-mail: patricia.de-cremoux@aphp.fr

Key Words: Breast cancer, neoadjuvant, COX2 inhibitors, chemotherapy, predictive, $C O X 2$. patients receiving celecoxib. The test for interaction between COX2 gene expression and the celecoxib effect was statistically significant $(p<0.01)$, but was not retained in the multivariate analysis. Conclusion: COX2 overexpression is predictive of pCR in patients with celecoxib-treated tumors. The efficacy of celecoxib in breast cancer might be improved by quantification of COX2 gene expression.

Many human cancers exhibit elevated prostaglandin levels due to up-regulation of cyclo-oxygenase-2 (COX2), a key enzyme in eicosanoid biosynthesis. COX2 overexpression has been observed in different malignant tumors and especially in breast cancer (1). Experimental studies showed that $\mathrm{COX} 2$ overexpression and a related production of prostaglandins stimulates angiogenesis and proliferation, promotes cell invasion and development of metastases (2). Consequently, selective COX2 inhibitors such as celecoxib have been explored as therapeutic or chemopreventive agents in different settings (3-5).

The level of COX2 has been associated with poor outcomes in many tumor models and clinical studies (6-8). However, there is no consensus on the prognostic or predictive value of $\mathrm{COX} 2$ expression in invasive breast carcinoma (9-11). Very few studies addressed the neoadjuvant context and response to celecoxib associated to chemotherapy in primary or metastatic breast cancer (12). 
Table I. Patient and tumor characteristics.

\begin{tabular}{lc}
\hline Variable & $\mathrm{n}(\%)$ \\
\hline Age (years) & \\
$<40$ & $34(22.3 \%)$ \\
40 to 49 & $66(43.4 \%)$ \\
$\geq 50$ & $52(34.2 \%)$ \\
Clinical tumor stage & \\
T2 & $88(57.9 \%)$ \\
T3 and T4 & $64(42.1 \%)$ \\
Clinical lymph node status* & \\
N0 & $57(37.8 \%)$ \\
N1, N2, N3 & $94(62.2 \%)$ \\
Histological subtype & $127(83.6 \%)$ \\
Ductal & $15(9.8 \%)$ \\
Lobular & $10(6.6 \%)$ \\
Other & \\
Elston-Ellis grade* & $13(8.8 \%)$ \\
I & $60(40.8 \%)$ \\
II & $74(50.3 \%)$ \\
III & $128(84.8 \%)$ \\
Lymphovascular invasion* & $23(15.2 \%)$ \\
No & \\
Yes & $54(35.5 \%)$ \\
ER & $98(64.5 \%)$ \\
Negative & \\
Positive & $83(55.7 \%)$ \\
PR* & $66(44.3 \%)$ \\
Negative & \\
Positive & $53(35.3 \%)$ \\
Triple-negative status & $99(64.7 \%)$ \\
Yes & \\
No & $89(58.6 \%)$ \\
No & $63(41.4 \%)$ \\
Yes & $132(86.8 \%)$ \\
pCR & $20(13.2 \%)$ \\
No Yes & \\
\hline & \\
\hline &
\end{tabular}

ER: Estrogen receptor; PR: progesterone receptor; pCR: pathological complete response. *Missing data: lymph node status, $\mathrm{n}=1$; grade, $\mathrm{n}=5$; lymphovascular invasion, $\mathrm{n}=1$; and $\mathrm{PR}, \mathrm{n}=3$.

One could expect to obtain better results with a better selection of patients receiving celecoxib. We present here data obtained in the human epidermal growth factor receptor 2 (HER2)-negative arm of the prospective neoadjuvant randomized phase II trial, REMAGUS-02 (R02), suggesting that the quantification of $C O X 2$ gene transcripts predicts the pathological response to neoadjuvant celecoxib associated with chemotherapy including anthracyclines and taxanes.

\section{Patients and Methods}

Patients. The present study concerns a series of 220 breast cancer samples from patients included in the HER2-negative arm of the prospective randomized phase II trial REMAGUS-02 (R02) for
Table II. Tumor characteristics in the subgroups of tumors with low and high levels of cyclo-oxygenase-2 (COX2) mRNA expression.

\begin{tabular}{|c|c|c|c|}
\hline \multirow[b]{2}{*}{ Variable } & \multicolumn{2}{|c|}{ COX2 mRNA expression } & \multirow[b]{2}{*}{$p$-Value } \\
\hline & Low n $(\%)$ & High n $(\%)$ & \\
\hline \multicolumn{4}{|l|}{ Age (years) } \\
\hline$<40$ & $23(22.5)$ & $11(22.0)$ & 0.99 \\
\hline 40 to 49 & $44(43.1)$ & $22(44.0)$ & \\
\hline$\geq 50$ & $35(34.3)$ & $17(34.0)$ & \\
\hline \multicolumn{4}{|c|}{ Clinical tumor stage } \\
\hline $\mathrm{T} 2$ & $61(59.8)$ & $27(54.0)$ & 0.61 \\
\hline $\mathrm{T} 3$ and $\mathrm{T} 4$ & $41(40.2)$ & $23(46.0)$ & \\
\hline \multicolumn{4}{|c|}{ Clinical lymph node status* } \\
\hline No & $36(35.3)$ & $21(42.9)$ & 0.47 \\
\hline $\mathrm{N} 1, \mathrm{~N} 2, \mathrm{~N} 3$ & $66(64.7)$ & $28(57.1)$ & \\
\hline \multicolumn{4}{|c|}{ Histological subtype } \\
\hline Ductal & $86(84.3)$ & $41(82.0)$ & 0.11 \\
\hline Lobular & $12(11.8)$ & $3(6.0)$ & \\
\hline Other & $4(3.9)$ & $6(12.0)$ & \\
\hline \multicolumn{4}{|c|}{ Elston-Ellis grade* } \\
\hline 1 & $11(10.9)$ & $2(4.3)$ & 0.01 \\
\hline 2 & $48(47.5)$ & $12(26.1)$ & \\
\hline 3 & $42(41.6)$ & $32(69.6)$ & \\
\hline \multicolumn{4}{|c|}{ Lymphovascular invasion* } \\
\hline No & $87(86.1)$ & $41(82.0)$ & 0.67 \\
\hline Yes & $14(13.9)$ & $9(18.0)$ & \\
\hline \multicolumn{4}{|l|}{ ER } \\
\hline Negative & $23(22.5)$ & $31(62.0)$ & $<0.01$ \\
\hline Positive & $79(77.5)$ & $19(38.0)$ & \\
\hline \multicolumn{4}{|l|}{$\mathrm{PR}^{*}$} \\
\hline Negative & $45(45.0)$ & $38(77.6)$ & $<0.01$ \\
\hline Positive & $55(55.0)$ & $11(22.4)$ & \\
\hline \multicolumn{4}{|c|}{ Triple-negative status } \\
\hline Yes & $22(21.6)$ & $31(62.0)$ & $<0.01$ \\
\hline No & $80(78.4)$ & $19(38.0)$ & \\
\hline
\end{tabular}

ER: Estrogen receptor; PR: progesterone receptor; pCR: pathological complete response. *Missing data: lymph node status, $\mathrm{n}=1$; grade, $\mathrm{n}=5$; lymphovascular invasion, $\mathrm{n}=1$; and $\mathrm{PR}, \mathrm{n}=3$. Significant data are indicated in bold.

patients with T2/T3/T4 advanced breast cancer. The patients were treated by sequential epirubicin/cyclophosphamide followed by docetaxel with or without the randomized addition of celecoxib (400 mg twice daily, orally) (arms A and B, respectively). Surgery was performed for 218 patients after eight cycle of chemotherapy, as previously described $(13,14)$. The primary objective of the trial was pathological complete response (pCR) evaluated according to Chevallier criteria (15). Secondary objectives were to define genomic profiles of success (pCR) or failure of each type of treatment and were published elsewhere together with quality control criteria (16-18).

The trial and ancillary studies were reviewed by the Ethics Committee of Bicêtre (CPP IDF VII), no. 03-55, 14th October 2004, in compliance with the Helsinki Declaration. All patients were informed and prospectively gave their signed consent to participate in the trial and ancillary studies,

Due to safety concerns, the use of celecoxib was suspended by the French Health Products Safety Agency (AFSSAPS) from 
Table III. Pathological response in patients as a function of tumor cyclo-oxygenase-2 (COX2) expression and celecoxib treatment.

\begin{tabular}{|c|c|c|c|c|c|c|}
\hline Population & Celecoxib & COX2 expression* & $\mathrm{n}$ & $\mathrm{pCR}, \mathrm{n}(\%)$ & OR $95 \% \mathrm{CI}$ & $p$-Value \\
\hline \multirow[t]{2}{*}{ Whole population $(\mathrm{n}=152)$} & No & - & 89 & $10(11.2 \%)$ & 1 & \\
\hline & Yes & - & 63 & $10(15.9 \%)$ & $1.49(0.57-3.87)$ & 0.407 \\
\hline \multirow[t]{2}{*}{ Whole population $(\mathrm{n}=152)$} & - & Low level & 102 & $7(6.9 \%)$ & 1 & \\
\hline & - & High level & 50 & $13(26 \%)$ & $4.77(1.81-13.58)$ & 0.002 \\
\hline \multirow[t]{2}{*}{ No celecoxib $(\mathrm{n}=89)$} & & Low level & 58 & $6(10.3 \%)$ & 1 & \\
\hline & & High level & 31 & $4(12.9 \%)$ & $1.28(0.31-4.89)$ & 0.716 \\
\hline \multirow[t]{2}{*}{ Celecoxib $(n=63)$} & & Low level & 44 & $1(2.3 \%)$ & 1 & \\
\hline & & High level & 19 & $9(47.4 \%)$ & $38.7(6.27-757)$ & 0.001 \\
\hline
\end{tabular}

pCR: Pathological complete response; OR: odds ratio; CI: confidence interval. *Low level=tertiles 1 and 2; high level=tertile 3. Significant data are indicated in bold.

December 2004 to September 2005 and thereafter authorized with revision of the informed consent form $(13,14)$. Thirteen patients randomized to receive celecoxib did not receive it. Consequently, the analyses were performed in the per protocol population.

Of the cases, 152 samples out of the 218 patients were available for reverse transcription and quantitative polymerase chain reaction (RT-qPCR) analysis on the basis of RNA of high quality from frozen pretreatment biopsies with more than $30 \%$ invasive epithelial tumor cells. There was no difference between the 152 patients with RT-qPCR data and the remaining 66 patients of the HER2-negative arm regarding age, menopausal status, clinical tumor size or nodal involvement, and hormone receptor status (data not shown).

Tissue samples and real-time RT-qPCR analysis. Total RNA extraction from frozen pretreatment biopsies, reverse transcription and qPCR analysis conditions and quality controls were previously described in detail (16-18). Primer and probe sequences for COX2 mRNA expression are available on request. Large ribosomal protein $(R P L P O)$, TATA box-binding protein $(T B P)$, transferrin receptor $(T F R)$, beta-actin $(A C T B)$, beta-glucuronidase $(G U S)$, and glyceraldehyde-3-phosphate dehydrogenase $(G A P D H)$ were used as endogenous reference genes. COX2 mRNA levels were normalized to the median of the six reference genes.

Statistical analysis. As no consensual threshold was defined for RTqPCR analyses and to ensure the robustness of the results, COX2 gene expression was arbitrarily split according to tertiles (low, intermediate and high). As the magnitude of odds ratios for pCR of the two lower tertiles (tertiles 1 and 2) was similar, we chose to group these two tertiles and analyze them (low and intermediate expression) versus the third one (tumors with the highest COX2 mRNA levels).

To analyze the association between clinical, pathological, COX2 mRNA and pCR data, we performed a univariate analysis using the chi-square test and a univariate logistic regression model to estimate odds ratios (OR) and their $95 \%$ confidence intervals.

Association between COX 2 expression (tertile $1 \& 2$ versus tertile 3 ) and pCR were performed.

Analyses were performed with R software, version 3.1.2 (R Development Core Team, 2011).

\section{Results}

Patient population. The characteristics of the population of 152 patients are described in Table I. Patients and tumor characteristics were similar in patients treated with and without celecoxib. However, the tumor characteristics were significantly different in subgroups with low $(n=102)$ and high $(\mathrm{n}=50)$ COX2 gene expression level (Table II). We observed higher rates of grade $3(69.6 \%$ versus $41.6 \%$, $p=0.01)$, ER-negative $(62.0 \%$ versus $22.5 \%, p<0.01)$ and PR-negative $(77.6 \%$ versus $45.0 \%, p<0.01)$ tumors in the population with the highest expression of $C O X 2$ when compared with the lower tertiles (Table II).

Pathological response. A pCR was observed in 20/152 patients $(13.2 \%)$. Considering the whole population, no effect of celecoxib was observed on tumor pCR $(15.9 \%$ in celecoxib-treated patients $v s .11 .2 \%$ in those without celecoxib; $p=0.41$ ) (Table III). However, the $\mathrm{pCR}$ rate was higher in the group of patients with highest tertile of COX2 in the overall population and in patients receiving celecoxib $(p=0.002)$ (Table III).

Taking into account the level of $C O X 2$ expression in patients who received celecoxib, the pCR rate was significantly higher in those with tumors with the highest tertile of $C O X 2(47.4 \%)$ than in those with low expression of COX2 $(2.3 \%)$ (Table III). The magnitude of the OR for pCR in the group of patients who received celecoxib suggested an interaction between $C O X 2$ gene expression and the effect of celecoxib. The test for interaction was statistically significant $(p<0.01)$, meaning that the effect of celecoxib on pCR was significantly different according to COX2 gene expression. On the contrary, in the arm without celecoxib, no difference in pCR rate was observed according to COX2 expression (Table III). However, after multivariate analysis, the interaction between celecoxib and $C O X 2$ 
expression failed to reach statistical significance $(p=0.12)$, and only initial tumor size (T3 and $\mathrm{T} 4$ versus $\mathrm{T} 2$ : $\mathrm{OR}=0.14$, 95\% $\mathrm{CI}=0.03-0.5, p=0.006)$ and $\mathrm{ER}$ status $(\mathrm{OR}=0.03,95 \%$ $\mathrm{CI}=0-0.12, p<0.001)$ were significantly associated with $\mathrm{pCR}$.

\section{Discussion}

In this biologically-driven analysis of the HER2-negative arm of the breast cancer neoadjuvant REMAGUS 02 trial, we found that $C O X 2$ expression analyzed by RT-qPCR could be a target for celecoxib treatment. The effect of celecoxib in addition to neoadjuvant chemotherapy was different according to COX2 expression level in patients with HER2negative breast cancer in terms of pCR. To our knowledge, this phase II neoadjuvant trial is the first to investigate in a prospective randomized trial the efficacy of the selective COX2 inhibitor celecoxib in addition to chemotherapy according to $C O X 2$ gene expression in breast cancer.

The main finding of the current study was that patients with high COX2 gene expression who received celecoxib had a significantly higher pCR rate compared with patients with low COX2 gene expression. It was previously shown in 42 patients with metastatic breast cancer patients treated with anthracyclines with and without taxanes, that the combination of celecoxib with capecitabine was more effective in patients overexpressing COX2 (19). Our results are also supported by interesting data published on lung cancer. Edelman et al. reanalyzed the negative results of the CALGB 30203 trial in advanced non-small cell lung cancer (20). Their analysis of the COX2 expression data indicate that the benefit of $400 \mathrm{mg}$ celecoxib twice per day was greatest in those with tumors with a higher level of $C O X 2$ expression $(20,21)$.

Regarding the relationship between COX2 and other tumor characteristics, we observed a positive correlation of COX2 overexpression with higher tumor grade, as observed in the recent retrospective Chilkman's study. Their study was designed for a subgroup of 303 high-grade breast cancers and they analyzed COX2 expression by immunohistochemistry (9). In contrast, they did not find any correlation with ER expression and only eight out of 18 studies cited in their article found an inverse correlation between ER and COX2 expression as observed in our study (9). Furthermore, in a recent study performed on a retrospective cohort of 446 breast carcinomas treated in the adjuvant setting where COX2 expression was analyzed by RT-qPCR, the authors found an inverse correlation between COX2 expression and ER and PR expression (22).

A recent meta-analysis including 21 studies and 6739 patients with breast cancer showed that the presence of high levels of COX2 predicts a greater tumor size and lymph node metastasis (11). The occurrence of COX2-overexpressing tumors in each study ranged from $27.9 \%$ to $81.4 \%$. As illustrated by this meta-analysis (11), most published studies on prognostic or predictive value of $\mathrm{COX} 2$ were performed using immunohistochemistry. But the methods used for immunohistochemical analysis of COX2 were diverse, with various antibodies, lack of standardization of staining, and analysis of tumor COX2 expression. Classifications of COX2 positivity and negativity differed significantly between published studies, which make comparisons between studies difficult. Recent studies pointed out several problems related to this method and explained discrepancies between studies. Urban et al. pointed out the importance of taking into account the stromal component of the tumor and not only epithelial cells, as is usually done (23). Only a few studies used RT-qPCR to assess COX2 expression (22, 24, 25). The main advantage of RT-qPCR is its truly quantitative approach but there is still no standardized method. However, this could be adapted, since to date, new standardized tests using quantification of target genes by RT-qPCR are available for routine use of a molecular signature for luminal breast cancer $(26,27)$. However, a recent publication showed a good correlation between COX 2 expression analyzed by immunohistochemistry and by RT-qPCR (22).

We conclude that $C O X 2$ expression in breast cancer is associated with histological type and grade, and inversely correlated with ER and PR expression. We also showed that higher COX2 expression is associated with an increase in pCR rate in patients treated with celecoxib. Taken together, our findings support the fact that drug trials using celecoxib should include pre-stratification by COX2 status. The efficacy of COX2 inhibitors in combination with chemotherapy might benefit from the quantitative evaluation of the target as a predictive biomarker (companion diagnosis). These results need to be confirmed in independent prospective study.

In this article, we included the essential elements of the Reporting Recommendations for Tumor Marker Prognostic Studies (REMARK) (28).

\section{Ethics Approval and Consent to Participation}

Remagus 02 trial: "A randomized phase II study of cytotoxic chemotherapy or cytotoxic chemotherapy combined with celecoxib or trastuzumab as primary chemotherapy for patients with high risk localized breast cancer not amenable to breast conserving therapy." was reviewed by the Ethic Committee of Bicêtre (CPP IDF VII), no. 03-55 14th October 2004.

\section{Competing Interests}

None of the Authors have any competing interest in regard to this study.

\section{Acknowledgements}

This work was supported by Academic Grants from the French Ministry of Health (French Programme Hospitalier de Recherche Clinique ISRCTN10059974, PHRC: AOM/2002/0211) and 
Industrial Grants from Pfizer Inc., Roche, Sanofi-Aventis ISRCTN100599. A.S. Hamy was supported by an ITMO-INSERMAVIESAN cancer translational research grant.

The Authors thank K. Tran-Perennou, C. Barbaroux and S. Vacher for their helpful technical contribution, and Dr. O. Tembo for clinical study monitoring. The Authors thank all the participants of the REMAGUS 02 trial.

\section{References}

1 Singh-Ranger G, Salhab M and Mokbel K: The role of cyclooxygenase- 2 in breast cancer: review. Breast Cancer Res Treat 109: 189-198, 2008.

2 Howe LR: Inflammation and breast cancer Cyclooxygenase/prostaglandin signaling and breast cancer. Breast Cancer Res 9: 210, 2007.

3 Evans JF and Kargman SL: Cancer and cyclo-oxygenase-2 (COX2) inhibition. Curr Pharm Des 10: 627-634, 2004.

4 Menter DG, Schilsky RL and DuBois RN: Cyclo-oxygenase-2 and cancer treatment: understanding the risk should be worth the reward. Clin Cancer Res 16: 1384-1390, 2010.

5 Regulski M, Regulska K, Prukała W, Piotrowska H, Stanisz B and Murias M: COX2 inhibitors: a novel strategy in the management of breast cancer. Drug Discov Today 21: 598-615, 2016.

6 Ristimäki A, Sivula A, Lundin J, Lundin M, Salminen T, Haglund C, Joensuu $\mathrm{H}$ and Isola J: Prognostic significance of elevated cyclo-oxygenase- 2 expression in breast cancer. Cancer Res 62: 632-635, 2002.

7 Denkert C, Winzer KJ, Müller BM, Weichert W, Pest S, Köbel M, Kristiansen G, Reles A, Siegert A, Guski H and Hauptmann $\mathrm{S}$ : Elevated expression of cyclo-oxygenase-2 is a negative prognostic factor for disease free survival and overall survival in patients with breast carcinoma. Cancer 97: 2978-2987, 2003.

8 Kim HS, Moon HG, Han W, Yom CK, Kim WH, Kim JH and Noh DY: COX2 overexpression is a prognostic marker for Stage III breast cancer. Breast Cancer Res Treat 132: 51-59, 2012 .

9 Chikman B, Vasyanovich S, Lavy R, Habler L, Tolstov G, Kapiev A, Halevy A and Sandbank J: COX2 expression in highgrade breast cancer: evidence for prognostic significance in the subset of triple-negative breast cancer patients. Med Oncol 31: 989, 2014.

10 Simonsson M, Björner S, Markkula A, Nodin B, Jirström K, Rose C, Borgquist S, Ingvar $\mathrm{C}$ and Jernström $\mathrm{H}$ : The prognostic impact of COX2 expression in breast cancer depends on oral contraceptive history, preoperative NSAID use, and tumor size. Int J Cancer 140: 163-175, 2017.

$11 \mathrm{Xu} \mathrm{F}$, Li M, Zhang C, Cui J, Liu J, Li J and Jiang H: Clinicopathological and prognostic significance of COX2 immunohistochemical expression in breast cancer: a metaanalysis. Oncotarget 8: 6003-6012, 2017.

12 Chuah BY, Putti T, Salto-Tellez M, Charlton A, Iau P, Buhari SA, Wong CI, Tan SH, Wong AL, Chan CW, Goh BC and Lee SC: Serial changes in the expression of breast cancer-related proteins in response to neoadjuvant chemotherapy. Ann Oncol 22: 1748-1754, 2011

13 Pierga JY, Delaloge S, Espié M, Brain E, Sigal-Zafrani B, Mathieu MC, Bertheau P, Guinebretière JM, Spielmann M, Savignoni A and Marty M: A multicenter randomized phase II study of sequential epirubicin/cyclophosphamide followed by docetaxel with or without celecoxib or trastuzumab according to HER2 status, as primary chemotherapy for localized invasive breast cancer patients. Breast Cancer Res Treat 122: 429-437, 2010.

14 Giacchetti S, Hamy AS, Delaloge S, Brain E, Berger F, SigalZafrani B, Mathieu MC, Bertheau P, Guinebretière JM, Saghatchian M, Lerebours F, Mazouni C, Tembo O, Espié M, Reyal F, Marty M, Asselain B and Pierga JY: Long-term outcome of the REMAGUS 02 trial, a multicenter randomised phase II trial in locally advanced breast cancer patients treated with neoadjuvant chemotherapy with or without celecoxib or trastuzumab according to HER2 status. Eur J Cancer 75: 323332, 2017.

15 Chevallier B, Roche H, Olivier JP, Chollet P and Hurteloup P: Inflammatory breast cancer Pilot study of intensive induction chemotherapy (FEC-HD) results in a high histologic response rate. Am J Clin Oncol 16: 223-228,1993.

16 de Cremoux P, Valet F, Gentien D, Lehmann-Che J, Scott V, Tran-Perennou C, Barbaroux C, Servant N, Vacher S, SigalZafrani B, Mathieu MC, Bertheau P, Guinebretière JM, Asselain B, Marty M and Spyratos F: Importance of pre-analytical steps for transcriptome and RT-qPCR analyses in the context of the phase II randomised multicentre trial REMAGUS02 of neoadjuvant chemotherapy in breast cancer patients. BMC Cancer 11: 215, 2011.

17 Valet F, de Cremoux P, Spyratos F, Servant N, Dujaric ME, Gentien D, Lehmann-Che J, Scott V, Sigal-Zafrani B, Mathieu MC, Bertheau P, Guinebretière JM, Pierga JY, Delaloge S, Giacchetti S, Brain E, Tembo O, Marty M and Asselain B: Challenging single- and multi-probesets gene expression signatures of pathological complete response to neoadjuvant chemotherapy in breast cancer: experience of the REMAGUS 02 phase II trial. Breast 22: 1052-1059, 2013.

18 Hamy AS, Bieche I, Lehmann-Che J, Scott V, Bertheau P, Guinebretière JM, Matthieu MC, Sigal-Zafrani B, Tembo O, Marty M, Asselain B, Spyratos F and de Cremoux P: BIRC5 (survivin): a pejorative prognostic marker in stage II/III breast cancer with no response to neoadjuvant chemotherapy. Breast Cancer Res Treat 159: 499-511, 2016.

19 Fabi A, Metro G, Papaldo P, Mottolese M, Melucci E, Carlini P, Sperduti I, Russillo M, Gelibter A, Ferretti G, Tomao S, Milella $\mathrm{M}$ and Cognetti F: Impact of celecoxib on capecitabine tolerability and activity in pretreated metastatic breast cancer: results of a phase II study with biomarker evaluation. Cancer Chemother Pharmacol 62: 717-725, 2008.

20 Edelman MJ, Watson D, Wang X, Morrison C, Kratzke RA, Jewell S, Hodgson L, Mauer AM, Gajra A, Masters GA, Bedor $\mathrm{M}$, Vokes EE and Green MJ: Eicosanoid modulation in advanced lung cancer: cyclo-oxygenase- 2 expression is a positive predictive factor for celecoxib + chemotherapy-Cancer and Leukemia Group B Trial 30203. J Clin Oncol 26: 848-55, 2008.

21 Edelman MJ, Wang X, Hodgson L,Watson D, Cheney RT , Baggstrom MQ, Sachdev T, Gajra A, Bertino EM, Reckamp KL, Molina J, Schiller J, Mitchell-Edwards K, Friedman P, Ritter J, Milne G, Stinchcombe TE, Hahn O and Vokes EE: Phase III randomized, placebo-controlled, double blind trial of celecoxib in addition to standard chemotherapy for advanced noon-smallcell lung cancer with cyclo-oxygenase-2 overexpression: CALGB 30801 J Clin Oncol 35: 2184-2192, 2017. 
22 Tury S, Becette V, Assayag F, Vacher S, Benoist C, Kamal M, Marangoni E, Bièche I, Lerebours F and Callens C: Combination of COX2 expression and PIK3CA mutation as prognostic and predictive markers for celecoxib treatment in breast cancer. Oncotarget 7: 85124-85141, 2016.

23 Urban J, Kuźbicki Ł, Szatkowski G, Stanek-Widera A, Lange D, and Chwirot BW: Stromal, rather than epithelial cyclooxygenase-2 (COX2) expression is associated with overall survival of breast cancer patients. BMC Cancer 14: 732, 2014.

24 Boneberg EM, Legler DF, Senn HJ and Fürstenberger G: Reduced expression of cyclo-oxygenase-2 in primary breast cancer. J Natl Cancer Inst 100: 1042-1043, 2008.

25 Fahlén M, Zhang H, Löfgren L, Masironi B, von Schoultz E, von Schoultz B and Sahlin L: Expression of cyclo-oxygenase-1 and cyclo-oxygenase-2, syndecan-1 and connective tissue growth factor in benign and malignant breast tissue from premenopausal women. Gynecol Endocrinol 33: 353-358, 2017.

26 Filipits M, Rudas M, Jakesz R, Dubsky P, Fitzal F, Singer CF, Dietze O, Greil R, Jelen A, Sevelda P, Freibauer C, Müller V, Jänicke F, Schmidt M, Kölbl H, Rody A, Kaufmann M, Schroth W, Brauch H, Schwab M, Fritz P, Weber KE, Feder IS, Hennig G, Kronenwett R, Gehrmann M, Gnant $M$ and EP Investigators: A new molecular predictor of distant recurrence in ER-positive, HER2-negative breast cancer adds independent information to conventional clinical risk factors. Clin Cancer Res 17: 6012-20, 2011.
27 Nielsen T, Wallden B, Schaper C, Ferree S, Liu S, Gao D, Barry G, Dowidar N, Maysuria M and Storhoff J: Analytical validation of the PAM50-based Prosigna Breast Cancer Prognostic Gene Signature Assay and nCounter Analysis System using formalinfixed paraffin-embedded breast tumor specimens. BMC Cancer 14: 177, 2014.

28 McShane LM, Altman DG, Sauerbrei W, Taube SE, Gion M, and Clark GM: REporting recommendations for tumor MARKer prognostic studies (REMARK). Nat Clin Pract Uro 2: 416-422, 2005.
Received December 5, 2017

Revised January 10, 2018

Accepted January 16, 2018 